\title{
Family Violence in the Educational Context: A Bibliometric Study
}

\author{
Gerardo Gómez García ${ }^{1}$, María Jesús Santos-Villalba ${ }^{2}$, Carmen Rodríguez Jiménez ${ }^{1}$ \& María José Alcalá del \\ Olmo Fernández ${ }^{3}$ \\ ${ }^{1}$ Facultad de Ciencias de la Educación, Universidad de Granada, Granada, España \\ ${ }_{2}^{2}$ Facultad de Ciencias de la Educación, Universidad Internacional de La Rioja, Logroño, España \\ ${ }^{3}$ Facultad de Ciencias de la Educación, Universidad de Málaga, Málaga, España \\ Correspondence: María Jesús Santos-Villalba, Facultad de Ciencias de la Educación, Universidad Internacional \\ de La Rioja, Logroño, España. E-mail: mariajesus.santos@unir.net
}

Received: November 14, 2020

doi:10.5539/ass.v17n2p44
Accepted: January 8, $2021 \quad$ Online Published: January 22, 2021

URL: https://doi.org/10.5539/ass.v17n2p44

\begin{abstract}
Family violence is one of the social problems that most concerns citizens today. Different subtypes of this violence continue to proliferate in the family context such as gender violence and child abuse. However, in recent years there has been an increase in cases of abuse of adolescent children towards their parents, giving rise to the phenomenon of child to parent violence. In order to analyse the scientific productivity of family violence, a bibliometric analysis was carried out. 679 scientific articles published from the date of origin of the subject to 2019 were analysed through the application of various bibliometric indicators. The results showed that the productivity on domestic violence is currently insufficient due to the existence of different types of violence that take place in the family nucleus and whose substantial elements differ from each other. Therefore, the need to continue contributing to research in this area of knowledge is reiterated.
\end{abstract}

Keywords: family violence, education, bibliometrics, teenager

\section{Introduction}

\subsection{Theoretical Framework}

Violence is one of the most alarming phenomena for our society today and it affects all countries considerably, regardless of their level of development. It is not a current event, but dates from historical tradition and generates serious physical and psychological consequences for those who witness it and for those who suffer it. According to the World Health Organization (WHO, 2002), violence is defined as: "The deliberate use of physical force or power, whether threatened or actual, against oneself, another person or a group or community, that causes or is likely to cause injury, death, psychological harm, developmental disorders or deprivation" (p. 5).

The 2016 WHO report includes some of the progress made between countries on violence, including child abuse, youth violence, sexual violence and abuse of the elderly (WHO, 2016). All abuse involves an imbalance of power and is exercised by the strongest to the weakest with the ultimate aim of exercising control over the relationship. In our society, the two main axes that produce this imbalance are age and gender, with women, older people and children suffering most from violence within the family (Nares, Martínez-García, \& Colín, 2015; Sanmartin, 2011).

Following this line of consideration, Rodríguez-Fernández (2018), states that domestic violence is made up of those acts or omissions, which intentionally cause damage of a physical, psychological and sexual nature. This also causes situations that lead to a lack of attention and result in negligence or abandonment.

There are various manifestations of domestic violence; among them, we can highlight gender violence. This type of violence can be defined as any behaviour that causes physical, psychological and/or sexual harm between people who have a sentimental bond (WHO, 2016). It is considered a phenomenon of great social relevance that can be triggered in all kinds of couples and at different times in the relationship (Aroca, Ros, \& Varela, 2016). According to data provided by the National Institute of Statistics (2018), women victims of gender-based violence in 2017 totalled 29,008 cases, increasing the percentage from the previous year by $14.8 \%$ among 18 -year-old women.

Child abuse, on the other hand, is identified as one of the most devastating forms of violence, calling into 
question traditional family models based on a culture of patriarchy from which serious consequences derive (Alonso-Gutiérrez et al., 2018; Bernal, García-Álvarez, \& Arteaga, 2018; McGuire \& London, 2020). In this way, domestic violence can also be called vertical and horizontal. It is called vertical when it goes from one hierarchical subsystem to another (from parents to children, from children to parents); and it is called horizontal when it occurs in the same subsystem, in the couple, between siblings, etc., (Barbolla, Masa, \& Diaz, 2011).

Vertical violence upwards or upward, has been called Filio-Parental Violence (Pereira, 2011). In Europe, until relatively recently, this type of violence has lacked interest, so that we currently find little scientific literature and the studies that have been carried out only use data from those cases that are reported, leaving in the shadows those others that remain hidden within the family. One of the difficulties that arose around the concept of Philio-Parental Violence (PPC) was the absence of agreement on definitions in order to arrive at a conceptualisation. In addition to the lack of consensus, the first definitions were brief and not very operationalised, and paid attention only to a small set of violent behaviours (Ibabe, Jaureguizar, \& Díaz, 2007).

The most current definition of FPV was proposed by the Expert Group of the SEVIFIP (Spanish Society for the Study of FPV) after an analysis of the different contributions of various authors (Aroca, 2010; Cottrell, 2001; Gallagher, 2004). This resulted in being able to reach an agreement on what can be understood about this type of violence and the categories that should be included and excluded. FPV would therefore be understood as:

"Repeated behaviour of physical, psychological (verbal or non-verbal) or economic violence, directed at parents or those who take their place. Excluded are punctual aggressions, those that occur in a state of diminished consciousness that disappear when the consciousness recovers (intoxications, abstinence syndromes, delirious states or hallucinations), those caused by psychological alterations (transitory or stable) (autism or severe mental deficiency) and parricide with no history of previous aggressions" (Pereira et al., 2017, p.220).

Currently, there seems to be a relatively majority consensus in recognising that what is new is not so much the phenomenon itself but its emergence in the public light. This fact can be derived because of either the existence of a greater social awareness and sensitivity in relation to this type of violence, or because of the increase in the number of cases reported, legislative advances or even the proliferation of specialised services in charge of working on this type of issue.

In analysing the data about the magnitude and impact of this problem situation, it is important to take into account several variables. Furthermore, knowing the frequency of this type of violence is quite complex, since both cultural and methodological factors largely condition a reliable estimate of the extent of this phenomenon (Martínez, Estévez, Jiménez, \& Velilla, 2015).

In the case of cultural variables, for example, it is very common to maintain an attitude of concealment of the situation due to shame. There can be cases where the fear of the reaction of the children themselves and the need to protect the family image, or some reactions of violence and aggressiveness of the children become normalised by the parents (Gallego, Novo, Fariña, \& Arce, 2019; Pérez \& Pereira, 2006; Santos-Villalba \& Leiva, 2020).

Different researches show that the prevalence rates of physical aggressions towards parents in the general population range from $4.6 \%$ to $21 \%$ (Calvete, Orue, \& Sampedro, 2011; Simmons, McEwan, Purcell, \& Ogloff, 2018), although these values increase considerably in samples belonging to young offenders, reaching values of up to 54\% (Del Hoyo-Bilbao, Gámez-Guadix, Orue, \& Calvete, 2018). In the same way, the rates of psychological aggressions are much higher than the rates corresponding to aggressions of a physical nature, presenting values that oscillate between 34\% and 93\% (Calvete, Orue, \& González-Cabrera, 2017). In addition, it should be noted that most of the research undertaken in the framework of philo-parental violence has shown that it is exercised to a much greater extent towards the figure of the mother, which can be explained by arguing that in most cases it is she who is most present in the upbringing of children (Calvete \& Veytia, 2018).

In recent years, there have been a number of studies of the same nature focusing on specific types of family violence. Thus, we find bibliometric scientific articles on gender violence (Arias, Velasco, \& Novo, 2016; Brilhante, Moreira, Vieira, \& Catrib, 2016) and others focused on child violence (Tran, et al., 2018; Vega-Arce \& Núñez-Ulloa, 2018).

\section{Method}

This study follows a methodology characteristic of bibliometric studies (Cruz, 1999). Bibliometric analysis is a methodology based on the study and evaluation of the production of research in a specific field on a given topic (Diem \& Wolter, 2013; Castillo \& Carreton, 2010). At first, the descriptors related to the subject matter to be studied have been established, having finally as a search equation the key words "FAMILY VIOLENCE" AND "EDUCATION". 
The search has been carried out during the first months of the year 2020 and has been done in the Scopus database, since it is a repository with great rigour and prestige in all the scientific documents it contains. In addition, this database has a series of characteristics that allow the limitation and selection of certain search indicators that facilitate and adapt their use to the preferences of each moment. In order to obtain the final sample ( $\mathrm{n}=704)$, the inclusion and exclusion criteria were applied as shown below (table 1):

Table 1. Inclusion and exclusion criteria used in the bibliometric analysis.

\begin{tabular}{ll}
\hline Inclusion criteria & Exclusion criteria \\
\hline Using the theme of family violence in education & Family violence unrelated to education \\
Scientific articles & Congress proceedings, book chapters, books, ... \\
Production until 2019 & The year 2020 as it is not yet completed \\
Only magazines as a source & Article in press (accepted without publication) \\
\hline
\end{tabular}

Note. Own production

Once the inclusion and exclusion criteria have been defined, we will proceed to define the questions, and therefore the objectives that motivate this work (Table 2).

Table 2. Research objectives, questions and indicators that will provide answers

\begin{tabular}{|c|c|c|}
\hline Objective & Question & Indicator \\
\hline $\begin{array}{l}\text { Evolution of the area and its } \\
\text { productivity }\end{array}$ & $\begin{array}{l}\text { When did the research treatment of } \mathrm{FV} \text { in } \\
\text { education originate? }\end{array}$ & $\begin{array}{l}\text { A.1. Number of articles and } \\
\text { years of publication }\end{array}$ \\
\hline (A) & $\begin{array}{l}\text { What has been the evolution of FV in } \\
\text { education? }\end{array}$ & $\begin{array}{l}\text { A.2. Diachronic productivity } \\
\text { and Price Law. }\end{array}$ \\
\hline $\begin{array}{l}\text { Characteristics of journals } \\
\text { dispersión of scientific production }\end{array}$ & $\begin{array}{l}\text { What are the main magazines that publish } \\
\text { about FV in education? }\end{array}$ & $\begin{array}{l}\text { B1. The most productive } \\
\text { magazines on the subject. }\end{array}$ \\
\hline (B) & $\begin{array}{l}\text { How are the articles distributed in the total } \\
\text { number of producing journals? }\end{array}$ & B2. Bradford’s Law. \\
\hline \multirow{4}{*}{$\begin{array}{l}\text { Productivity of the autor and more } \\
\text { prolific institutions. } \\
\text { (C) }\end{array}$} & Who are the most prolific authors? & \multirow{4}{*}{$\begin{array}{l}\mathrm{C} 1 \text {. List of authors plus } \\
\text { producers on FV. } \\
\text { C2. List of the most prolific } \\
\text { institutions. } \\
\text { C3. Lotka's Law. }\end{array}$} \\
\hline & What is their citation level and impact rate? & \\
\hline & Which institutions are the most productive? & \\
\hline & $\begin{array}{l}\text { Does the level of authors' contribution follow a } \\
\text { particular pattern? }\end{array}$ & \\
\hline $\begin{array}{l}\text { More researched topics } \\
\text { sample. }\end{array}$ & $\begin{array}{l}\text { What topics are most addressed within FV and } \\
\text { education? }\end{array}$ & $\begin{array}{l}\text { D1. List of the most frequently } \\
\text { discussed topics. }\end{array}$ \\
\hline (D) & $\begin{array}{l}\text { What are the key words and the connection } \\
\text { between them in the different articles? }\end{array}$ & $\begin{array}{l}\text { D2. Map of connection } \\
\text { between key descriptors. }\end{array}$ \\
\hline
\end{tabular}

\section{Note. Own production}

\section{Results}

\subsection{Evolution of the Area and Its Productivity}

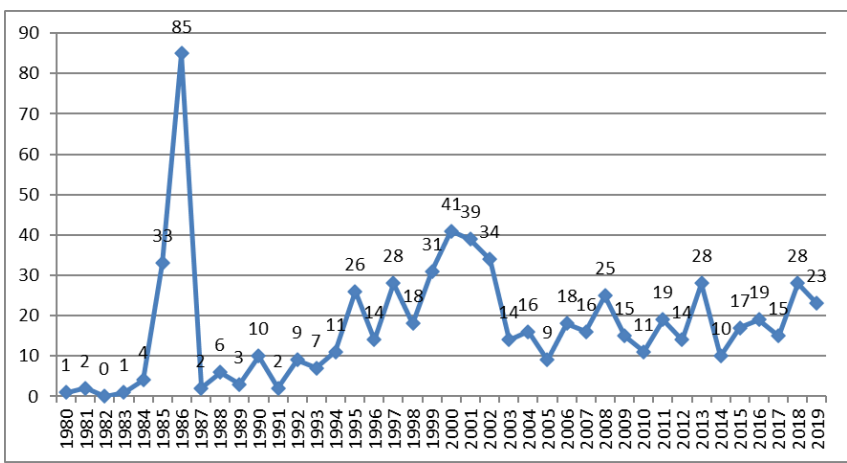

Figure 1. Diachronic productivity of family violence in education from 1980 to 2019

\section{Note. Own production}

With regard to the production indicators, the diachronic productivity is specified in figure 1 . If we look at the literature, we can see that at the beginning in the year 1980 it only has 1 document $(0.14 \%)$ and that the 
exponential growth is found from the year 1994 (1.56\%), reaching its maximum level in the year 1986 with 85 documents $(12.07 \%)$. In this case, Price's Law is not fulfilled, because we do not find any period of 10-15 years in which there is a duplication of scientific literature (Price, 1986).

\subsection{Characteristics of Journals and Dispersion of Scientific Production}

The Bradford's Law indicates that a small number of journals, in this case called the core, concentrate a number of articles that is equal to or very similar to those grouped in other zones (zones 1 and 2) which are proportional to the number of documents in the core (Miranda, 1990). Similarly, it is shown how scientific journals are grouped into several zones that encompass approximately the same number of articles as in the nucleus (figure 2). The total is 402 journals and 704 articles, distributed in three zones with an average of 250 articles each, where it can be seen that the nucleus with 16 journals has a very similar number of articles as the rest of the zones.

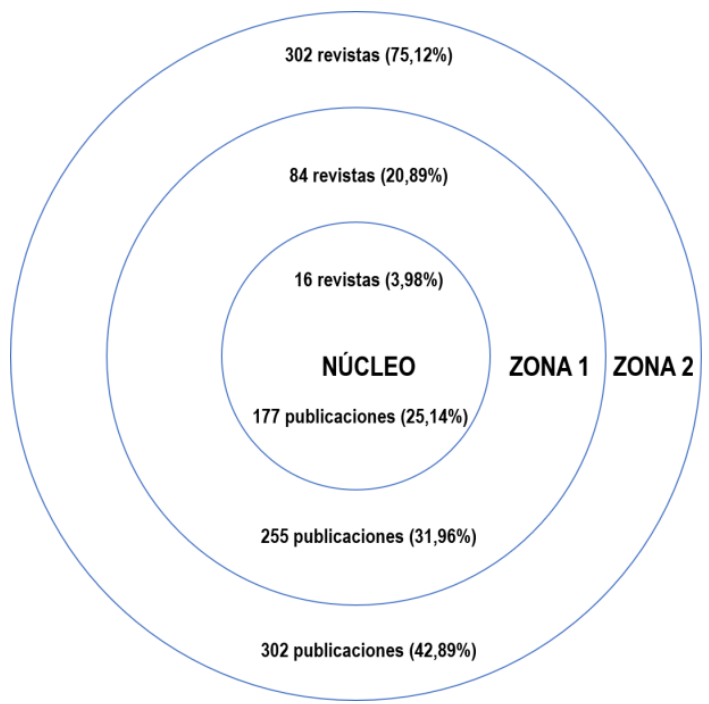

Figure 2. Bradford's dispersal area of scientific journals on family violence in education Note. Own production

With regard to the most productive journals, figure 3 shows the $10(2.48 \%)$ which concentrate a considerable number of publications, in this case 147 articles $(20.88 \%)$. Thus, we can see how the two journals that accumulate the most scientific articles in this respect have only one document of difference, these are Child Abuse Neglect and Academic Medicine, with 27 and 26 files respectively. The following journals have considerably fewer articles, 16 and 14 respectively (Journal of Family Violence and Violence and Victims). The other journals, no longer suffer a jump of this size in the number of documents, but these are progressively decreasing as we advance in the journals of the subject.
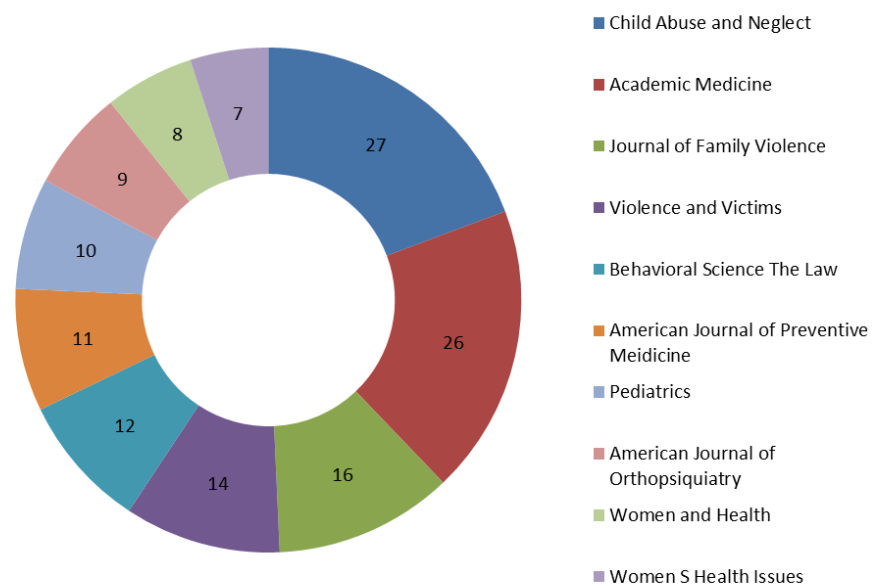

Figure 3. More productive magazines in the area of family violence and education Note. Own production 


\subsection{Author's Productivity and Most Prolific Institutions}

The impact indicators presented below have been divided into three factors which allow us to know the level of influence of family violence in the educational environment as an object of study.

Firstly, it is a question of knowing the most prolific authors at the same time as evaluating them (table 3 ). In this case, the author with the highest scientific productivity is Short with a total of 6 contributions, followed by Alpert (4) and Caspers (3). However, these authors do not correspond to those with the highest impact index, in that case we find Fullerton ( $\mathrm{I}=1872$ ) and Gerbert ( $\mathrm{I}=1153)$.

Table 3. Authors with the largest number of scientific articles on Family Violence and Education

\begin{tabular}{cccccc}
\hline Author & $\begin{array}{c}\text { Number of } \\
\text { documents }\end{array}$ & $\%$ & Cites & $\begin{array}{c}\text { Impact } \\
\text { rate }\end{array}$ & Institution \\
\hline Short, L.M. & 6 &, $88 \%$ & 442 & 73,6 & Analytic Systems Associates, Inc. \\
Alpert, E.J. & 4 &, $58 \%$ & 588 & 147 & $\begin{array}{c}\text { The University of British Columbia } \\
\text { Caspers, N. }\end{array}$ \\
$\begin{array}{c}\text { Christoffersn, } \\
\text { M.N. }\end{array}$ & 3 &, $44 \%$ & 664 & 221,3 & University of California, San Francisco \\
$\begin{array}{c}\text { Fullerton, C.S. } \\
\text { Gerbert, B. }\end{array}$ & 3 &, $44 \%$ & 468 & 156 & Danish National Centre for Social Research \\
Gervais, A. & 3 &, $44 \%$ & 5616 & 1872 & Uniformed Services University of the Health \\
Hadley, S.M. & 3 &, $44 \%$ & 1804 & 601,3 & Sciences \\
Haj-Yahia, M.N. & 3 &, $44 \%$ & 75 & 25 & University of California, San Francisco \\
Haley, N. & 3 &, $44 \%$ & 2135 & 711,6 & Gouvernement du Québec \\
\hline
\end{tabular}

Note. Own production

In this same line of authors, Lotka's law establishes that most of the scientific articles published come from a small number of specialised authors and that the rest of the articles are written by a considerable number of authors. This study confirms this premise. As can be seen in figure 4, where its logarithmic regression was plotted, it is stated that the distribution of scientific articles according to the number of authors follows a tendency of this nature, towards unity. The coefficient obtained in the calculation of the logarithmic model is $\mathrm{R}=0.8644$, which indicates a high value of similarity between what is expressed in the model and the reality of the data distribution.

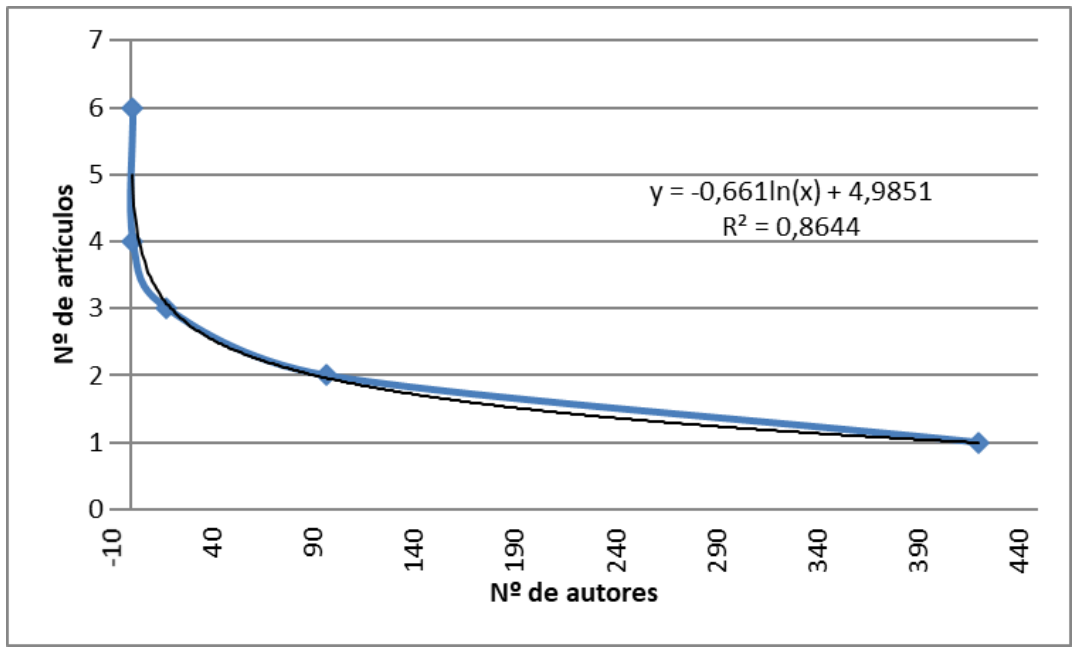

Figure 4. Correlation between number of authors and number of papers

Note. Own production

With regard to the most outstanding institutions in terms of scientific production on family violence and education (Table 4), it can be seen that the North American universities and study centres (The University of 
North Carolina at Chapel Hill, Harvard Medical School, Centers for Disease Control and Prevention, John Hopkins University, etc.) comprise almost the entirety of documents on family violence related to education. It is followed by universities in Australia (University of Melbourne).

Table 4. Institutions with the highest number of articles on family violence and education

\begin{tabular}{ccccc}
\hline Institutions & Number of documents & $\%$ & Cited & Impact rate \\
\hline The University of North Carolina at Chapel Hill & 11 & $1,56 \%$ & 657 & 59,72 \\
Harvard Medical School & 9 & $1,27 \%$ & 335 & 37,22 \\
University of Melbourne & 9 & $1,27 \%$ & 212 & 23,55 \\
University of Montreal & 8 & $1,13 \%$ & 764 & 95,5 \\
Centers for Disease Control and Prevention & 7 & $0,99 \%$ & 133 & 19 \\
National Center for Injury Prevention and Control & 7 & $0,99 \%$ & 421 & 60,14 \\
University of Toronto & 7 & $0,99 \%$ & 282 & 40,28 \\
Johns Hopkins University & 6 & $0,85 \%$ & 380 & 63,33 \\
University of Washington, Seattle & 6 & $0,85 \%$ & 591 & 98,5 \\
University of Witwatersrand & 6 & $0,85 \%$ & 168 & 28 \\
\hline
\end{tabular}

Note. Own production

\subsection{Most Researched Topics Within the Sample}

Before to the analysis of the most researched topics within the panorama of FV and education, it is convenient to clarify the intention of the articles, which we distinguish through the following structuring:

- Prevention of domestic violence, despite being intrinsic to all the articles, we differentiate a wide body of articles that covers the study of different predictive variables in different subjects that can prevent domestic violence.

- Experiences or data collection of subjects who have suffered some kind of domestic violence, through different measuring instruments of different nature, and their inferential analysis. Proposals for improvement and reinvestment of this situation are provided.

Once this was described, based on the sample $(n=704)$ considered for the present study, an analysis of the main themes in the papers studied was carried out and a percentage of the amount represented by that theme with respect to the entire sample was established.

- Gender violence (65\%), whose articles are focused on the study of possible psychological, socio-economic and intra-family predictors that give an indication of this situation, as well as bibliographical studies on the importance of awareness of this fact and social reality. The study of a qualitative nature through interviews and the collection of testimonies as an instrument for the collection of data from different samples from various study contexts stands out. The study of the resilience of the victims, the importance of this, and the proposal of actions and programmes based on psychiatry and psychological therapy to be able to reinvest these fatal experiences in possible cases of depression, mental illness or suicide are also carried out.

- Violence of parents against children, that is to say, the study of child abuse (15\%) occupies the pages of numerous scientific documents in which the various causes that have consequently this event are highlighted, such as the consumption of drugs, mental disorders and severe stress, which lead to the degree of sexual, physical and psychological aggression. Of note are multivariate studies in which children and adolescents are questioned in a quantitative way about possible aggressions of a physical or emotional nature suffered by parents, the interviewing of testimonies of subjects who participate in the research and correlations between different variables such as aggressive behaviour, feeling of depression and its relationship with the aggression.

- Filio-parental violence (15\%) in which adult children mistreat and assault their parents, normally of advanced age. The study of this subject lies in the characteristics of the profile of the aggressor child, the influence of variables such as drug consumption, alcohol, school failure, illness, among others. Therefore, studies of a quantitative nature are highlighted in which an attempt is made to establish binding relationships between different dependent and independent variables that have an influence. Programmes of educational reinsertion for those students who find themselves in this situation stand out.

- The "new" filio-parental violence (5\%), a concept understood by several authors (Aroca, 2010; Pereira, 2011), in which adolescent children attack their parents. The study of this subtype of domestic violence focuses on the analysis of family characteristics and the profile of the aggressor child. Triggering factors revolve around 
a lack of clear rules and boundaries in the home and dysfunctional roles played by parents. It is worth mentioning the existence of some psycho-educational intervention programmes which aim to provide families with tools to re-establish links and improve coexistence.

\subsection{Bibliometric Map}

Finally, through the VOSviewer software, a software specialised in the creation of nodal networks between the key words that are repeated in each article, a map of networks between descriptors is created, which shows the relationships between the key words used in the different articles on domestic violence in the educational context. As can be seen in figure 5, three differentiated groups or clusters are distinguished, each with a different colour. The size of the concepts indicates their frequency of appearance and greater number of connections between other descriptors.

If we look at the bibliometric map (figure 5), we can distinguish three clusters, each one defined by a specific colour. Firstly, we find the set of concepts in red, in which "human" stands out as the one that is most often repeated among the articles that make up the sample, followed by "female", "article" and "domestic violence". In the compendium of blue concepts, we find "education", "psychological aspect" and "child abuse", that is, education, psychological aspect and child abuse. Finally, in the green cluster, which is the one with the smallest nodes, we find significant terms such as "adolescent", "controlled study" or "family", terms that are linked to philo-parental violence described above.

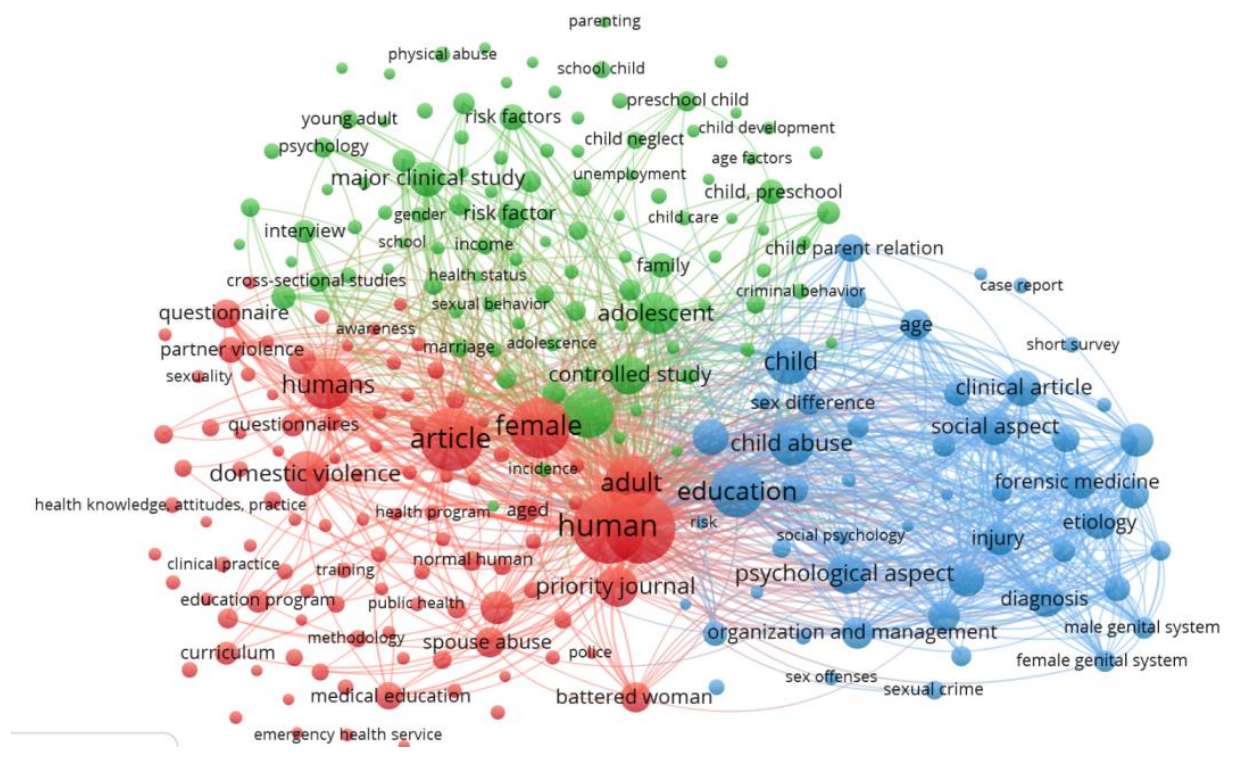

Figure 5. Map of connection between key descriptors

Note. Own production

\section{Discussion}

The research that has been carried out allows us to extract the metadata from the scientific production regarding Family Violence and Education. In this way, 704 documents have been found which are concentrated over the years, but which do not follow an ascending course in terms of production, but rather find several high points in this trajectory, as in the years 1986 and 2000, and more recently 2013 and 2019. This new increase in scientific literature concerning domestic violence, regardless of its type, in recent years may be due, as Alonso-Gutiérrez et al. (2018) and Bernal et al. (2018) indicate, to changes and rethinking of the traditional patriarchal models that have prevailed in society until now. In the same line, different researches in the last decades (Aroca, 2010; Cottrell, 2001; Gallagher, 2004; Gallego et al., 2019; Pereira, 2011; Pereira et al., 2017; Simmons et al., 2018) have led to the conceptualisation of a new type of violence, the filio-parental, which has as a factor of interest not so much the existence of this one in itself, but the importance of its social visibility. In this respect, different authors have established the reasons why there are no more known cases of this type of violence and, therefore, it is not possible to investigate too much about it, its causes, its consequences, its possible solutions, etc. (Martínez et al., 2015; Pérez \& Pereira, 2006; Santos-Villalba \& Leiva, 2020). In practically all authors who study the different types of violence in depth, a common approach coexists; for example, Calvete and Veytia (2018) highlight that the most vulnerable figure and the one who receives the violence in most cases, whether it is physical or psychological, is that of the woman, a woman as a mother, an elderly person, an adolescent or a 
wife.

With regard to the most productive journals where articles on our subject are found, it can be observed that a large part of them are related to the areas of medicine and paediatrics ("Academic Medicine", "Behavioral Science the Law", "American Journal of Preventive Medicine"). This could be because of the violence and its different manifestations are identified as a problem that must be studied and solved by doctors, psychologists, among other professionals in the same field. However, there is not a true representation of journals in the educational field in this sense, which leads to the recognition that the pedagogical factor is not really considered a determining factor in solving this problem or has not been considered of scientific interest in this area of knowledge until now. Furthermore, if we look at the bibliometric map shown above, we see that the key words of greater size are domestic violence, intimate partner violence, screening, medical education, among others. This means that the most predominant violence as an object of study is domestic violence, without taking into account the different variables of the same, and that the few references to education that are made are referred to the medical field as a preventive and resolution area.

This work aims to demonstrate the enormous presence of family violence in our society, the different types of family violence that we can find and how these typologies, which differ in substantial elements, are addressed and studied. As we have been saying, there are different types of family violence, among them, filio-parental violence, which in recent years is being postulated as the subtype that is most investigated given the importance and need for cases of this type to be reported. This may lead us to think that in the coming years a real boom in scientific research in this area may be possible.

Family violence is an overwhelming reality in today's society, which is why many cases are not reported out of fear, shame or incapacity. This lack of visibility in the face of a problem of great magnitude is what causes scientific production on the subject to oscillate between such disparate values depending on the moment. For this reason, by way of conclusion, it is important to stress that a future deepening of how to educate young people from the classroom to make visible and give voice to an endemic problem of our society is necessary, not only to really know the cases to be faced, but also to establish action and training plans that manage to reduce the percentages of this reality.

In addition to the above, it is necessary to assume and work under a pedagogical paradigm of a culture of peace, being decisive to investigate in how many actions and educational proposals are able to impregnate the various social and cultural representations. It is necessary to take into account in which family violence is present, as a way of offering effective response to an alarming situation and at the same time object of commitment and responsibility from the educational framework.

\section{References}

Alonso-Gutiérrez, G. M., Martínez-Gómez, C., Peralta, H., Ballbé, A., García-Perez, R., \& Giance, L. (2018). Modelo de la dinámica del proceso de promoción de salud frente al maltrato infantil. Mediciego, 24(2), 62-77. Retrieved from http://www.revmediciego.sld.cu/index.php/mediciego/article/view/931/1400

Arias, E., Velasco, J., \& Novo, M. (2016). Análisis bibliométrico sobre la investigación en violencia de género. fundamentos y nuevas tendencias. Avances En Psicología Juridica y Forense, 13, 81-91. https://doi.org/10.13140/RG.2.1.2594.2807

Aroca, C. (2010). La violencia filio-parental: una aproximación a sus claves (Tesis Doctoral). Universidad de Valencia. Valencia.

Aroca, Ros, \& Varela. (2016). Programa para el contexto escolar de prevención de violencia en parejas adolescentes. Educar, 52(1), 11-31. https://doi.org/10.5565/rev/educar.673

Barbolla, D., Masa, E., \& Díaz, G. (2011). Violencia invertida. Cuando los hijos pegan a sus padres. Barcelona: Editorial Gedisa.

Bernal, R. E., García-Álvarez, I., \& Arteaga, R. (2018). Propuesta de estrategia pedagógica para la prevención del maltrato infantil desde la educación inicial. Revista Conrado, 14(65), 367-373. Retrieved from http://conrado.ucf.edu.cu/index.php/Conrado

Brilhante, A. V. M., Moreira, G. A. R., Vieira, L., \& Catrib, A. M. F. (2016). Um estudo bibliométrico sobre a violência de gênero. Saúde e Sociedade, 25(3), 703-715. https://doi.org/10.1590/s0104-12902016148937

Calvete, E., Orue, I., \& González-Cabrera, J. (2017). Violencia filio parental: comparando lo que informan los adolescentes y sus progenitores. Revista de Psicología Clínica con Niños y Adolescentes, 4, 9-15. Retrieved from http://www.revistapcna.com/es/contenido/46 
Calvete, E., Orue, I., \& Sampedro, R. (2011). Violencia filio-parental en la adolescencia: Características ambientales y personales. Infancia y Aprendizaje, 34(3), 349-363. Retrieved from https://psycnet.apa.org/doi/10.1174/021037011797238577

Calvete, E., \& Veytia, M. (2018). Adaptación del Cuestionario de Violencia Filio-Parental en Adolescentes Mexicanos. Revista Latinoamericana de Psicología, 50(1), 49-60. Retrieved from https://psycnet.apa.org/doi/10.14349/rlp.2018.v50.n1.5

Castillo, A., \& Carreton, M. (2010). Research in communication. bibliometric study in journals of communication in Spain. Comunicacion y Sociedad, 23(2), 289-327. Retrieved from https://revistas.unav.edu/index.php/communication-and-society/article/view/36234/30664

Cottrell, B. (2001). Parent abuse: The abuse of parents by their teenage children. Canadá: The Family Violence Prevention Unit Health. Retrieved from htpp://www.canadiancre.com/parent_abuse.htm

Cruz, M. (1999). Bibliometría y Ciencias Sociales. Clío: History and History Teaching, 7, 1-10. Retrieved from http://clio.rediris.es/clionet/articulos/bibliometria.htm

Del Hoyo-Bilbao, J., Gámez-Guadix, M., Orue, I., \& Calvete, E. (2018). Psychometric properties of the Child-to-Parent Aggression Questionnaire in a clinical sample of adolescents who abuse their parents: Prevalence and gender differences. Violence and Victims, 33(2), 203-217. http://doi.org/10.1891/0886-6708

Diem, A., \& Wolter, S. (2013). The use of bibliometrics to measure research performance in education sciences. Research in Higher Education, 54(1), 86-114. Retrieved from http://www.jstor.org/stable/23355360

Gallagher, E. (2004). Parents victimised by their children. Australian and New Zealand Journal of Family Therapy, 25(1), 1-12. https://doi.org/10.1002/j.1467-8438.2004.tb00573.x

Gallego, R., Novo, M., Fariña, F., \& Arce, R. (2019). Child-to-parent Violence and Parent-to-child Violence: A Meta-analytic Review. European Journal of Psychology Applied to Legal Context, 11(2), 51-59. https://doi.org/10.5093/ejpalc2019a4

Ibabe, I., Jauregizar, J., \& Díaz, O. (2007). Violencia filio-parental: conductas violentas de jóvenes hacia sus padres. Vitoria-Gasteiz: Servicio Central de Publicaciones del Gobierno Vasco. Retrieved from http://www.jusap.ejgv.euskadi.net/r47-edukia/es/contenidos/informe_estudio/violencia_filio_parental/es_vif ilpar/adjuntos/Violencia_Filio-Parental.pdf

Instituto Nacional de Estadística. (2018). Estadística de Violencia Doméstica y Violencia de Género Año 2017. Registro Central para la Protección de las Víctimas de la Violencia Doméstica y de Género en el que se inscriben víctimas con orden de protección o medidas cautelares. Titularidad del Ministerio de Justicia. Recuperado de: https://www.ine.es/prensa/evdvg_2017.pdf

Martínez, M. L., Estévez, E., Jiménez, T. I., \& Velilla, C. (2015). Violencia filo-parental. Principales características, factores de riesgo y claves para la intervención. Papeles del Psicólogo, 3, 216-223. Retrieved from http://www.papelesdelpsicologo.es/pdf/2615.pdf

McGuire, K., \& London, K. (2020). A retrospective approach to examining child abuse disclosure. Child Abuse Negl, 99, 104263. https://doi.org/10.1016/j.chiabu.2019.104263

Miranda, A. (1990). Bibliometría. Bibliotecas, 8(1), 1-11. Retrieved from https://www.revistas.una.ac.cr/index.php/bibliotecas/article/view/761

Nares, N., Martínez-García, D. G., \& Colín, R. (2015). Violencia de género en la familia: Perspectiva jurídico penal. Revista Científica Multidisciplinaria de Prospectiva, 22(2), 116-124. Retrieved from https://www.redalyc.org/pdf/104/10439327002.pdf

Organización Mundial de la Salud (2002). Informe mundial sobre la violencia y la salud. Retrieved from http://whqlibdoc.who.int/publications/2002/9275324220_spa.pdf

Organización Mundial de la Salud (2016). Informe sobre la situación mundial de la prevención de la violencia. Washington, D. C.: World Health Organization 2014 Global Status Report on Violence Prevention.

Pereira, R. (2011). Psicoterapia de la violencia filio-parental: Entre el secreto y la vergüenza. Madrid: Morata.

Pereira, R. (2015). Family Dynamics and Therapeutic Intervention. En A., Holt. (coord.) Working with Adolescent Violence and Abuse Towards Parents: Approaches and Contexts for Intervention (pp.80-99). London \& New York: Routledge.

Pereira, R., Loinaz, I., del Hoyo-Bilbao, J., Arrospide, J., Bertino, L., Calvo, A., \& Gutiérrez, M.M. (2017). 
Propuesta de definición de violencia filio-parental: consenso de la sociedad española para el estudio de la violencia filio-parental (servifip). Papeles del Psicólogo, 38(3), 216-223. http://doi.org/10.23923/pap. psicol2017.2839

Pérez, T., \& Pereira, R. (2006). Violencia Filio-Parental: Revisión de la Bibliografía. Revista Mosaico, 36, 1-13. Retrieved from https://www.redalyc.org/articulo.oa?id=77842122007

Price, D. J. S. (1986). Little Science, big science ... and beyond. Nueva York, NY: Columbia University Press.

Rodríguez-Fernández, A. G. (2018). Violencia intrafamiliar y colectivos especialmente vulnerables: menores y ancianos. Apuntes desde un enfoque interdisciplinar. Revista Interdisciplinar de Doctrina y Jurisprudencia, 19, 1-25. Retrieved from http://ojs.ual.es/ojs/index.php/RIDJ/article/view/2196/2709

Sanmartín, J. (2011). Maltrato infantil en la familia en España. Madrid: Ministerio de Sanidad, Política Social e Igualdad.

Santos-Villalba, M. J., \& Leiva, J. J. (2020). Actitudes sobre la Violencia Filio-Parental de los profesionales de la educación egresados de la Universidad de Málaga (España). Revista Espacios, 41(2), 29-41. Retrieved from https://www.revistaespacios.com/a20v41n02/a20v41n02p29.pdf

Simmons, M., McEwan, T. E., Purcell, R., \& Ogloff, J. R. (2018). Sixty years of child-to-parent abuse research: What we know and where to go. Aggression and Violent Behavior, 38, 31-52. https://doi.org/10.1016/j.avb.2017.11.001

Tran, B., Pham, T., Ha, G., Ngo, A., Nguyen, L., Vu, T., Do, H. N., Nguyen, V., Le Nguyen, A. T.; Tran, T., Truong, N. T., Hoang, V. Q., Ho, T. M., Dam, N. V., Vuong, T. T., Nguyen, H. Q., Le, H. T., Do, H. T., Moir, M., Shimpuku, Y., Dhimal, M., Arya, S. S., Nguyen, T. H., Bhattarai, S., Latkin, C. A., Ho, C., \& Ho, R. (2018). A bibliometric analysis of the global research trend in child maltreatment. International Journal of Environmental Research and Public Health, 15(7), 1456. https://doi.org/10.3390/ijerph15071456

Vega-Arce, M., \& Núñez-Ulloa, G. (2018). Experiencias adversas en la infancia: Mapeo bibliométrico de la literatura científica en la web of science. Revista Cubana De Información En Ciencias De La Salud (ACIMED), 29(1), 25-40. Retrieved from http://scielo.sld.cu/scielo.php?script=sci_arttext\&pid=S230721132018000100003

\section{Copyrights}

Copyright for this article is retained by the author(s), with first publication rights granted to the journal.

This is an open-access article distributed under the terms and conditions of the Creative Commons Attribution license (http://creativecommons.org/licenses/by/4.0/). 